\title{
Differential Susceptibility of Anthurium Cultivars to Bacterial Blight in Foliar and Systemic Infection Phases
}

\author{
H. Fukui, A. M. Alvarez, and R. Fukui, Department of Plant Pathology, University of Hawaii at Manoa, Honolulu \\ 96822-2279
}

\begin{abstract}
Fukui, H., Alvarez, A. M., and Fukui, R. 1998. Differential susceptibility of anthurium cultivars to bacterial blight in foliar and systemic infection phases. Plant Dis. 82:800-806.

Susceptibility of anthurium cultivars to systemic infection by the bacterial blight pathogen, Xanthomonas campestris pv. dieffenbachiae, was examined using a bioengineered bioluminescent strain (V108LRUH1) and compared with susceptibility to foliar infection. Eight cultivars with different levels of susceptibility to foliar infection were evaluated for their susceptibility to systemic infection. Petioles of second youngest leaves cut near the main stem were inoculated with strain V108LRUH1, and subsequent movement of this bacterium into other petioles was monitored by observing bioluminescence from the plants. The actual extent of systemic movement was determined by reisolating V108LRUH1 from dissected segments of the remaining petioles. In susceptible cultivars, the pathogen advanced very rapidly and nearly reached the distal end of petioles. In resistant cultivars, the pathogen was detected in none (or very few) of the petiole segments. However, the susceptibility ranking among the tested cultivars for systemic infection did not always correspond to the ranking determined for foliar infection: i.e., one cultivar that was susceptible to foliar infection was highly resistant to systemic infection, and vice versa. This suggests that cultivar susceptibility of anthuriums to bacterial blight may differ depending on the phase of disease progression, and thus evaluation for both disease phases is essential for complete understanding of cultivar susceptibility.
\end{abstract}

Bacterial blight of anthurium (Anthurium andraeanum Lind. ex André), caused by Xanthomonas campestris pv. dieffenbachiae, is an important disease in Hawaii as well as other tropical-subtropical regions. In Hawaii, the disease was first reported on the island of Kauai (11), and it was described as a nonsystemic blight, causing only foliar symptoms, similar to foliar blight in other aroids $(18,24,35)$. Subsequently, the disease was not observed until 1980, when anthurium blight was reported on several commercial farms on the island of Hawaii, the major production area (22). Unlike in the first report, the disease in the 1980s was not restricted to leaves or spathes; the pathogen advanced systemically and killed susceptible plants (20). The disease caused a severe decline in production and became a serious problem statewide in the late 1980s $(30,31)$.

Corresponding author: R. Fukui

E-mail: ryo@hawaii.edu

This research was supported in part by the U.S. Department of Agriculture/Special Grants Program for Tropical and Subtropical Agricultural Research (Agreement No. 96-34135-2841). Journal Series No. 4322 of the Hawaii Institute of Tropical Agriculture and Human Resources.

Accepted for publication 24 March 1998.

Publication no. D-1998-0520-02R

(C) 1998 The American Phytopathological Society
Anthurium blight is difficult to control in Hawaii, since latent infections and aerosols containing the pathogen perpetuate the disease in the mild climate $(1,3,23)$. Use of tissue cultured plants certified to be pathogen-free by the triple indexing system (3234) combined with strict sanitation practices (21) was successful in reducing disease incidence but did not eradicate the disease from production fields. Breeding for disease resistance is a desirable strategy for maintaining flower production in the presence of the disease, and a variety of resistant (tolerant) cultivars have been introduced (13-16). However, use of such cultivars does not solve the problem entirely because of high market demand for susceptible cultivars having desirable flower shapes and colors. In addition, infected tolerant cultivars may provide inoculum for long periods if left in the field undetected (7) and eventually succumb to the disease. In general, susceptibility of anthurium cultivars has been evaluated by their "field performance," and the role of foliar and systemic infections on cultivar susceptibility has not been well defined. For instance, some cultivars that show little foliar blight succumb rapidly to systemic infection. Other cultivars are severely affected by foliar blight, but they survive for long periods in the field with no evidence of systemic infection. Cultivar susceptibility to the foliar infection phase was accurately evaluated using a bioluminescent strain of $X$. campestris pv. dieffen- bachiae (7). However, no study has been made to determine which phase(s) of the disease (foliar or systemic) is more important for classification of cultivar susceptibility.

Unlike foliar infections, which are revealed by various types of symptoms, systemic infection is difficult to assess since it advances without apparent symptoms until the infected plant wilts and collapses. Wounds created during flower harvest or defoliation provide unprotected invasion sites for the pathogen, which is easily transmitted with contaminated cutting tools or by rain splash. Systemic infection initiated by such means does not usually produce foliar symptoms. This caused some growers to believe that foliar blight and systemic blight are two different diseases. Nematode damage, fungal root rots, and nutrient deficiency also cause wilts that resemble systemic blight (21). Because of the lack of well-defined visible symptoms, studies on systemic movement of the pathogen have not been carried out in depth. More information on the infection process in systemic blight and factors associated with disease resistance are needed to improve the current disease management practices.

Bioluminescence is a valuable tool for studying systemic blight. It has been used effectively to monitor the process of foliar infection by $X$. campestris in anthurium (7) and other crops $(4,27,28)$ by detecting light emission from infected leaves. This technique allows us to monitor and quantify the progression of systemic infection over time without destroying the plants. The objectives of this study were to develop a quantitative method for measuring the extent of systemic infection in anthurium plants using a bioluminescent strain of $X$. campestris pv. dieffenbachiae, and to evaluate susceptibility of various anthurium cultivars to systemic infection. Preliminary reports of this work have been published $(5,6)$.

\section{MATERIALS AND METHODS}

Plant materials and growth conditions. Eight cultivars of anthurium were used in this study: Alii (UH908), ARCS (UH1068), Kalapana (UH1016), Marian Seefurth, Nitta, Pink Elf (UH1070), Tropic Mist (UH780), and UH1060 (no common name). Plants potted in cinder medium were obtained from growers on the island of Hawaii. All plants were grown in a 
glasshouse shaded with two layers of saran sheet $(<10 \%$ of full sunlight) and watered every other day until use.

Four weeks before inoculation, all plants were taken out of their original pots, barerooted, repotted into $10 \times 10 \mathrm{~cm}$ pots with new cinder medium, and fertilized with pellets of Nutricote (13-13-13 plus microelements in a 70-day release formulation; Chisso Asahi Co., Tokyo, Japan) at a rate of about $0.65 \mathrm{~g}$ of fertilizer per pot. All plants had healthy root systems with no signs of damage or rot at the time of transplanting. Plants were 25 to $40 \mathrm{~cm}$ tall when inoculated.

The pathogen and inoculation procedure. The pathogen used was a bioluminescent strain, V108LRUH1, of X. campestris pv. dieffenbachiae $(2,5)$. This strain was produced by mating a local wild-type strain (V108) resistant to rifampin with Escherichia coli HB101 (pUCD623) and HB101 (pRK2013), a recombinant helper strain. Plasmid UCD623 harbored a transposon sequence ( $\mathrm{Tn} 4431)$ encoding the lux gene (29). The transposon was integrated into the chromosome of the recipient, which expressed stable bioluminescence after three passages (inoculation and reisolation) through the host plants (R. McElhaney, unpublished). Strain V108 was selected as the recipient, because it was representative of a large group of strains of $X$. campestris pv. dieffenbachiae, as judged by the results of pathogenicity tests on anthuriums, host-range tests on various aroids, and serotyping (19). The presence of the lux genes in the bacterium was verified by growth and production of light from the colonies on 523 medium (12) amended with rifampin at $50 \mu \mathrm{g} / \mathrm{ml}$ and tetracycline at $10 \mu \mathrm{g} / \mathrm{ml}$.

Inoculum was prepared by growing V108LRUH1 on agar plates of peptoneglucose medium $(1.0 \%$ peptone, $0.5 \%$ glucose, and $1.7 \%$ agar) for 2 days at $28^{\circ} \mathrm{C}$. The second youngest leaves were used for the inoculation since the youngest leaves were at different developmental stages (from emerging to fully mature) among the test plants. The petiole of the second youngest leaf was cut with a disinfested scalpel, leaving a $2.5-\mathrm{cm}$ section at the base. Cells of V108LRUH1 were inoculated directly to the cut petiole end, which was then capped tightly with a disposable pipette tip. The tip end was melted to prevent the inoculation site from drying. Inoculated plants were placed in the greenhouse and arranged in a balanced, randomized complete block (RCB) design with seven or eight blocks. The sealed cap was cut off at the tip the following day for gas exchange and removed from the inoculation sites a week later. The plants were watered at soil level every other day to prevent the pathogen from splashing onto the foliage.

Cultivar susceptibility to systemic infection was evaluated in three experiments with seven replicates per cultivar (experiment I) or eight replicates per cultivar (experiments II and III). Eight cultivars were evaluated in total, and all cultivars except for Nitta were evaluated in at least two separate experiments. Cultivars ARCS, Kalapana, Marian Seefurth, and Tropic Mist were evaluated in three separate experiments. The daily minimum and maximum temperatures (average and one standard deviation) in the greenhouse during the experiments were $22.0 \pm 0.8^{\circ} \mathrm{C}$ and $27.0 \pm 1.7^{\circ} \mathrm{C}$ in experiment $\mathrm{I}$ (June to July 1995$), 21.9 \pm 1.0^{\circ} \mathrm{C}$ and $26.4 \pm 1.1^{\circ} \mathrm{C}$ in experiment II (October to November 1995), and $18.6 \pm 1.6^{\circ} \mathrm{C}$ and $24.0 \pm 1.9^{\circ} \mathrm{C}$ in experiment III (February to March 1996). The maximum light intensity (wavelength of 400 to $700 \mathrm{~nm}$ ) at the experimental section of the greenhouse was 30 to $45 \mu \mathrm{mol} \mathrm{m} \mathrm{m}^{-2} \mathrm{~s}^{-1}$ (measured around 2 P.M. on sunny days).

Quantification of systemic movement of the pathogen. Inoculated plants were periodically observed in the dark for bioluminescence at the inoculation sites and remaining petioles, and the extent of systemic infection was assessed by reisolating the bacterium 4 to 6 weeks after the inoculation. The remaining petioles (the youngest leaf was designated as leaf \#1, and the leaves older than the inoculated leaf were designated as leaf \#3, \#4, \#5, and
\#6 according to their ages) were detached at the base and surface-disinfested by wiping with $70 \%$ ethanol. Each petiole was marked at 2-cm intervals from the base and sectioned into $1-\mathrm{cm}$ segments from the distal to proximal end using a disinfested blade on a disinfested cutting board. If a plant had a flower, flower stem (peduncle) also was sectioned for reisolation of the pathogen. The sectioned petiole segments were placed sequentially (proximal end down) into individual wells of a white 96well microfluor plate (Dynatec Laboratories Inc., Chantilly, VA) filled with $150 \mu \mathrm{l}$ per well of 523 liquid medium amended with rifampin, tetracycline, and $100 \mu \mathrm{g}$ of cycloheximide per ml. After soaking for 30 min, the petiole segments were removed from the wells, and microfluor plates were placed inside plastic containers and incubated at $28^{\circ} \mathrm{C}$. After incubation for 3 days, plates were agitated at room temperature on a rotary shaker $(180 \mathrm{rpm})$ for $1 \mathrm{~h}$ and observed in a dark room for light emission from wells to determine which petiole sections had released the pathogen into the medium.

In a separate test, several $1-\mathrm{cm}$ segments of infected Pink Elf petioles that were bioluminescent were further sectioned into eight small pieces and immersed in $1 \mathrm{ml}$ of $10 \mathrm{mM}$ phosphate buffer $(\mathrm{pH} 6.9)$ for $1 \mathrm{~h}$ to estimate cell density of the pathogen in
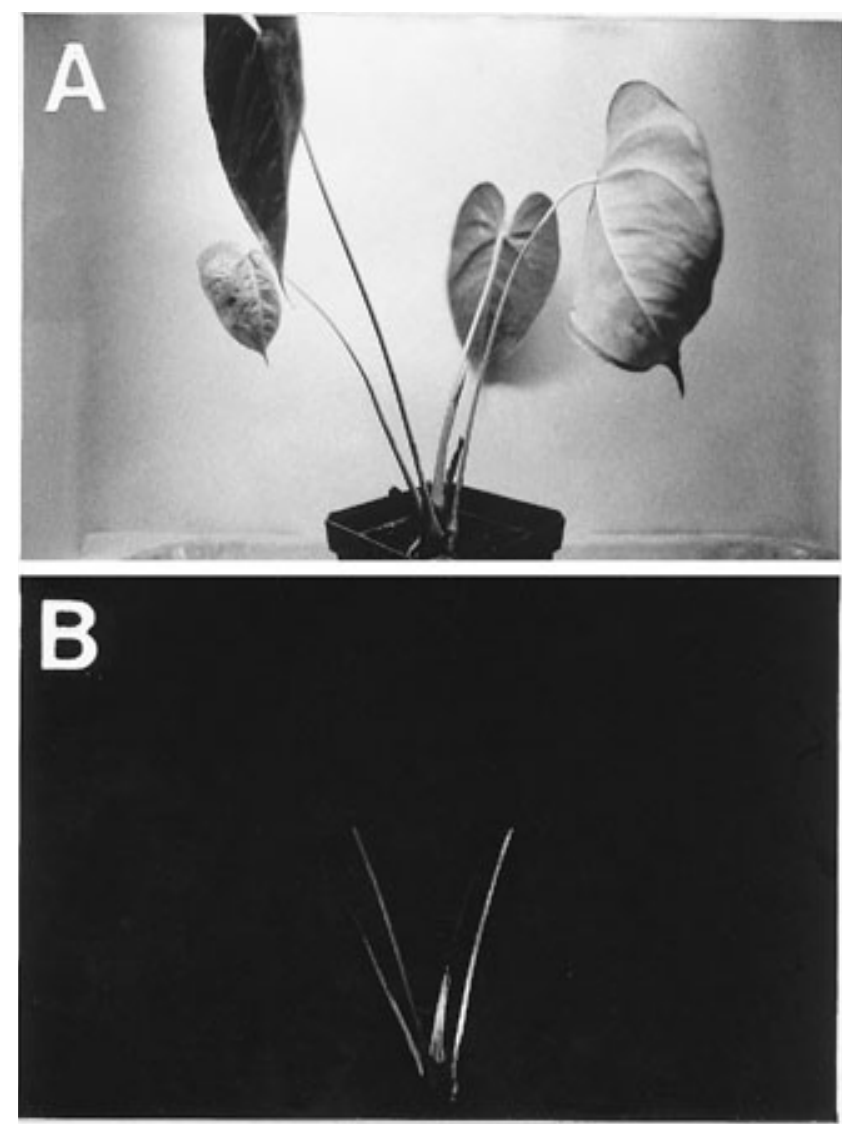

Fig. 1. A Marian Seefurth anthurium plant systemically infected by bioluminescent strain V108LRUH1 of Xanthomonas campestris pv. dieffenbachiae when viewed under daylight (A) and in the dark (B). 
each 1-cm petiole segment. Buffer solution with minced petiole pieces in tubes was vortexed for $1 \mathrm{~min}$ and then dilution plated onto peptone-glucose medium containing rifampin, tetracycline, and cycloheximide.

Susceptibility of eight anthurium cultivars to foliar infection by strain V108LRUH1. The eight cultivars tested for systemic infection were also tested for their susceptibility to foliar infection. Six of eight cultivars tested in this study were previously evaluated for their susceptibility to foliar infection using the bioluminescent strain: Kalapana and Tropic Mist were resistant; ARCS, Marian Seefurth, Pink Elf, and UH1060 were susceptible. Susceptibility of Alii and Nitta has not been evaluated with the bioluminescent strain. To evaluate their relative position in the resistance-susceptibility ranking, all eight cultivars were tested using the method described previously (7).

The plants used for this test were grown under the same conditions as susceptibility tests for systemic infection. The experiment was conducted in a balanced RCB design with eight replicates. Disease was assessed 38 and 54 days after inoculation, and percentages of infected leaf area were expressed as disease severity indices (thus a value of disease severity index corresponds to a percentage value for infected leaf area). The average minimum and maximum temperatures in the greenhouse during the experiment (March to May 1996) were $20.5 \pm 1.5^{\circ} \mathrm{C}$ and $26.1 \pm 1.4^{\circ} \mathrm{C}$, respectively. The test was conducted once.

Root inoculation. Five plants of Kalapana and Marian Seefurth were pulled from the pots, bare-rooted, and repotted into new cinder (in $10 \times 10 \mathrm{~cm}$ pots) to create root wounds. Another five plants also were bare-rooted, and four main rootlets in each plant were randomly clipped (at 4 to $6 \mathrm{~cm}$ from the main stem) before repotting into new cinder. The last set of five plants was undisturbed (not transplanted). Cells of strain V108LRUH1 grown on peptone-glucose agar plates for 2 days were suspended in sterile distilled water, and the cell concentration of this bacterial suspension was adjusted to an optical density of 0.1 at $600 \mathrm{~nm}\left(\cong 10^{8}\right.$ $\mathrm{CFU} / \mathrm{ml}$ ) using a spectrophotometer. The suspension was diluted 10 -fold with distilled water $\left(\cong 10^{7} \mathrm{CFU} / \mathrm{ml}\right)$ and used for inoculation. Each pot was covered with a plastic bag and placed inside another $10 \times$ $10 \mathrm{~cm}$ pot. Inoculum was then poured into the pot to soak the entire root system and

Table 1. The average values for systemic movement of Xanthomonas campestris pv. dieffenbachiae V108LRUH1 in various anthurium cultivars

\begin{tabular}{|c|c|c|c|c|c|c|c|c|}
\hline \multirow[b]{2}{*}{ Exp. } & \multirow[b]{2}{*}{ Cultivar } & \multicolumn{6}{|c|}{ Distance $(\mathbf{c m})$ at which V108LRUH1 was detected in petioles and flower stems ${ }^{a}$} & \multirow{2}{*}{$\begin{array}{c}\text { Average among } \\
\text { petioles \#1-4 }\end{array}$} \\
\hline & & \#6 & $\# \mathbf{5}$ & \#4 & $\# \mathbf{3}$ & $\# 1$ & Flower & \\
\hline \multirow[t]{8}{*}{$\mathrm{I}^{\mathrm{c}}$} & Kalapana & $0.0^{* \mathrm{~d}}$ & $0.0^{*}$ & 0.0 & 0.7 & 0.0 & $5.0^{*}$ & $0.2 \mathrm{~A}$ \\
\hline & ARCS & $0.0^{*}$ & 0.0 & 0.0 & 0.0 & 2.6 & $0.0^{*}$ & $0.9 \mathrm{~A}$ \\
\hline & Alii & $1.7^{*}$ & 1.3 & 2.1 & 5.6 & 8.4 & $-\mathrm{e}$ & $5.4 \mathrm{AB}$ \\
\hline & Nitta & $4.5^{*}$ & $3.5^{*}$ & 4.0 & 6.1 & 11.1 & $7.5^{*}$ & $7.1 \mathrm{AB}$ \\
\hline & Pink Elf & 1.9 & 3.6 & 3.1 & 9.4 & 9.0 & $1.3^{*}$ & $7.2 \mathrm{AB}$ \\
\hline & Tropic Mist & - & $10.8^{*}$ & 12.9 & 12.3 & 14.4 & $7.3^{*}$ & $13.2 \mathrm{~B}$ \\
\hline & Marian Seefurth & $13.8^{*}$ & $11.2^{*}$ & 10.3 & 15.9 & 16.4 & $17.5^{*}$ & $14.2 \mathrm{~B}$ \\
\hline & Average & 3.6 & 4.3 & 4.6 & 7.1 & 8.9 & 6.4 & \\
\hline \multirow[t]{14}{*}{ II $^{\mathrm{f}}$} & ARCS & $0.0^{*}$ & 0.0 & 0.0 & 0.0 & 0.0 & 3.8 & $0.0 \mathrm{~A}$ \\
\hline & & {$[17.4]^{\mathrm{g}}$} & {$[19.4]$} & [22.0] & [23.4] & [21.1] & [32.1] & \\
\hline & Kalapana & - & - & $0.0^{*}$ & 0.9 & 2.3 & - & $1.4^{\mathrm{h}}$ \\
\hline & & {$[-]$} & {$[-]$} & [28.0] & [23.1] & [25.4] & - & \\
\hline & Pink Elf & 0.0 & 0.9 & 0.0 & 3.6 & 7.0 & $0.0^{*}$ & $3.5 \mathrm{~A}$ \\
\hline & & [25.8] & [26.4] & [28.6] & [31.5] & [25.1] & [36.5] & \\
\hline & Tropic Mist & - & $2.0^{*}$ & 3.1 & 6.3 & 4.4 & $7.5^{*}$ & $4.6 \mathrm{~A}$ \\
\hline & & {$[-]$} & [22.3] & [23.8] & [28.1] & [30.4] & [34.5] & \\
\hline & UH1060 & $9.2^{*}$ & $18.1^{*}$ & 17.4 & 5.5 & 4.1 & $10.8^{*}$ & $9.0 \mathrm{~A}$ \\
\hline & & [20.8] & [27.7] & [34.5] & [38.6] & [32.4] & [21.8] & \\
\hline & Marian Seefurth & $10.8^{*}$ & 13.4 & 15.6 & 13.8 & 23.0 & $3.0^{*}$ & $17.5 \mathrm{~B}$ \\
\hline & & [17.8] & [19.9] & [25.6] & [26.4] & [30.4] & [41.0] & \\
\hline & Average & 5.0 & 6.9 & 6.0 & 5.0 & 6.8 & 5.0 & \\
\hline & & [20.4] & [23.1] & [27.1] & [28.5] & [27.5] & [33.2] & \\
\hline \multirow[t]{14}{*}{ III $^{\mathrm{i}}$} & ARCS & $0.0^{*}$ & 0.0 & 0.0 & 0.0 & 0.0 & 0.0 & $0.0 \mathrm{~A}$ \\
\hline & & [19.2] & [21.4] & [19.1] & [20.3] & [22.9] & {$[30.6]$} & \\
\hline & Kalapana & $0.0^{*}$ & $0.0^{*}$ & 0.3 & 0.1 & 1.0 & $1.2^{*}$ & $0.5 \mathrm{~A}$ \\
\hline & & [32.0] & [28.3] & [28.0] & [29.9] & [35.3] & [44.8] & \\
\hline & Alii & - & - & $1.3^{*}$ & 1.4 & 5.0 & $0.0^{*}$ & $2.6 \mathrm{AB}$ \\
\hline & & {$[-]$} & {$[-]$} & [16.9] & [22.8] & [27.5] & {$[40.0]$} & \\
\hline & UH1060 & 10.0 & 7.3 & 8.4 & 7.3 & 14.0 & $0.7^{*}$ & $9.9 \mathrm{BC}$ \\
\hline & & [21.3] & [24.0] & [27.5] & [29.4] & [30.6] & [26.0] & \\
\hline & Tropic Mist & $6.0^{*}$ & 10.3 & 12.6 & 13.6 & 16.9 & $9.3^{*}$ & $14.4 \mathrm{C}$ \\
\hline & & {$[25.0]$} & [29.6] & [29.6] & [34.1] & [35.3] & [32.3] & \\
\hline & Marian Seefurth & $13.2^{*}$ & $13.6^{*}$ & 18.0 & 21.4 & 24.4 & $19.0^{*}$ & $21.3 \mathrm{D}$ \\
\hline & & [21.6] & [25.0] & [26.4] & [29.5] & [29.8] & [31.0] & \\
\hline & Average & 5.8 & 6.2 & 6.8 & 7.3 & 10.2 & 5.0 & \\
\hline & & [23.8] & [25.7] & [24.6] & [27.6] & {$[30.2]$} & [34.1] & \\
\hline
\end{tabular}

\footnotetext{
${ }^{a}$ Mean value of seven replicates in experiment I or eight replicates in experiments II and III.

${ }^{\mathrm{b}}$ Data from petioles \#1, \#3, and \#4 were used for statistical analysis (21 or 24 observations in total). Mean values followed by the same letters are not significantly different according to Student-Newman-Keuls test $(\alpha=0.01)$.

${ }^{c}$ According to analysis of variance, the effects of cultivar and leaf age were significant $(P=0.002$ and 0.026 , respectively) with no significant interaction between two effects $(P>0.05)$.

${ }^{\mathrm{d}}$ Values indicated with asterisks were means of less than eight replicates (seven in experiment I) since some plants lacked the petiole.

e No petiole sampled.

${ }^{\mathrm{f}}$ The effect of cultivar was significant $(P<0.001)$. The effect of leaf age was not significant $(P>0.05)$. The cultivar-by-leaf age interaction was significant $(P<0.001)$

$\mathrm{g}$ The numbers in brackets are the average length of petiole or peduncle $(\mathrm{cm})$. The length of petiole was not measured in experiment $\mathrm{I}$.

${ }^{\mathrm{h}}$ In experiment II, six plants of Kalapana lacked leaf \#4; thus, the data from Kalapana were omitted from statistical analysis.

${ }^{i}$ The effects of cultivar and leaf age were significant $(P<0.001$ and $P=0.023$, respectively) with no significant interaction between two effects $(P>$ $0.05)$.
} 
incubated overnight at room temperature. The pots were removed from the suspension, drained, and returned to the greenhouse. Eight pellets of Nutricote were given to each plant except for the undisturbed plants. The plants were watered daily and observed weekly for 15 weeks in the dark for bioluminescence emission surviving plants were sectioned to reisolate the pathogen from tissues 16 weeks after inoculation. Tissues randomly taken from the root, main stem, and lower parts of petioles were ground in $10 \mathrm{mM}$ phosphate buffer $(\mathrm{pH}$ 6.9), and the aliquots were placed on plates of 523 medium containing the two pathogen-specific antibiotics and cycloheximide. The average minimum and maximum temperatures in the greenhouse during the experiment (April to July 1994) were $22.4 \pm 1.6^{\circ} \mathrm{C}$ and $29.5 \pm 1.8^{\circ} \mathrm{C}$, respectively. This test was conducted once.

Statistical analysis. Statistical analysis for the degree of systemic infection was performed using data only from leaf petioles \#1, \#3, and \#4, since some of the cultivars lacked flowers and/or leaves \#5 and \#6. The data for the Kalapana in experiment II were omitted from analysis since many of those plants lacked leaf petiole \#3. Systemic movement of $X$. campestris pv. dieffenbachiae through the petioles was measured in centimeters, and data were analyzed by analysis of variance using Microsoft Excel Version 4.0 (Microsoft from main stems and/or the petioles. All

Corporation, Redmond, WA). The petiole number (leaf age) was considered as the repeated measure in a factorial arrangement. Statistical analysis for severity of foliar infection was described previously (7). Means were separated by StudentNewman-Keuls (SNK) test.

\section{RESULTS}

Movement of $X$. campestris pv. dieffenbachiae monitored by bioluminescence and evaluation of cultivar susceptibility to systemic infection. Bioluminescence was observed in petioles and main stems of inoculated plants (Fig. 1). Two weeks after inoculation, bioluminescence was detectable from the inoculation site but not from any other plant parts in all cultivars. In the third to fourth week, light emission advanced to the main stem and other petioles (and peduncle) depending on the cultivar. In some cases, bioluminescence was also seen in lateral air-roots stretching into the cinder. However, in many plants of ARCS and Kalapana, bioluminescence had become undetectable from the inoculation sites by this time and was never observed from any other parts of these plants afterward. Although systemic movement of the pathogen in the petioles was detected by bioluminescence, exact measurement of systemic movement by bioluminescence was not feasible since the light diffused along the petiole. In addition, unlike in assessment of foliar infection,

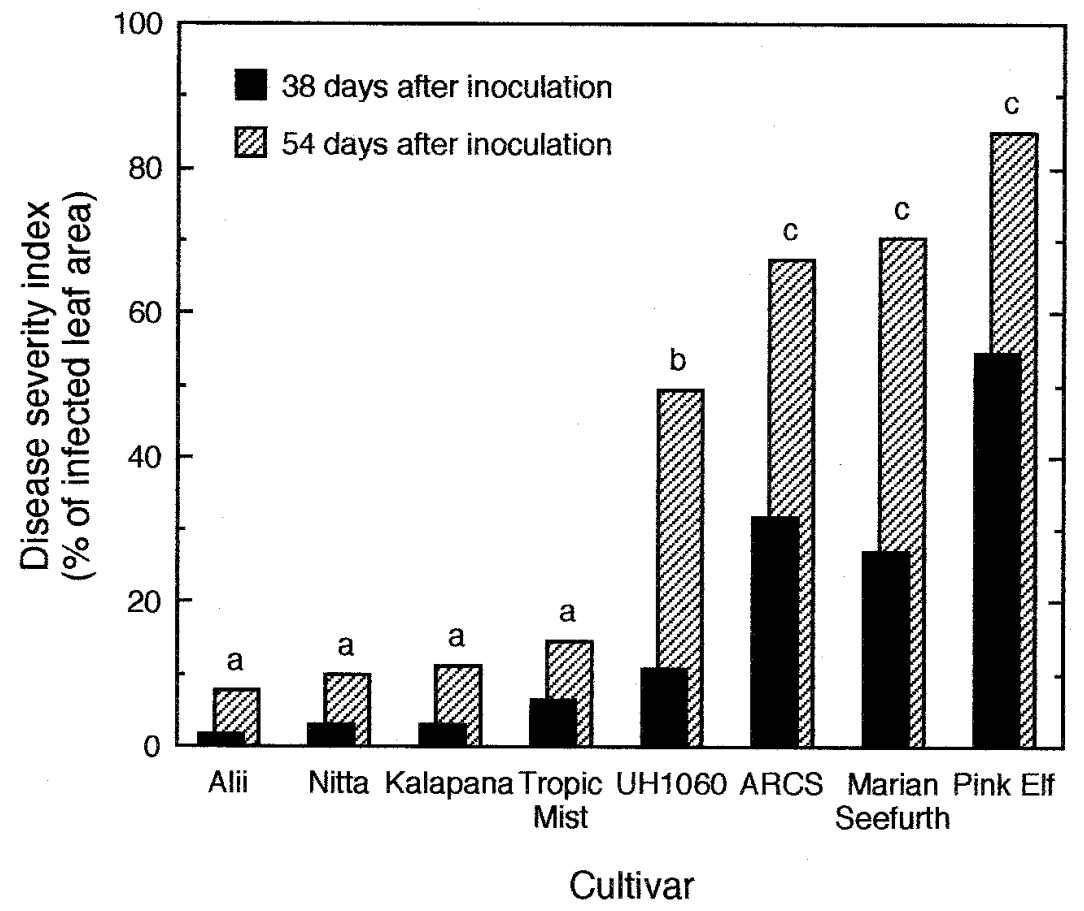

Fig. 2. Severity of leaf infection in various anthurium cultivars inoculated with a bioluminescent strain (V108LRUH1) of Xanthomonas campestris pv. dieffenbachiae. Bars represent average values of eight replicates. According to analysis of variance, the effects of cultivar and assessment day (repeated measure factor) were both significant at $P<0.001$. The cultivar-by-assessment day interaction was significant at $P=0.001$. Values indicated by the same letter are not significantly different according to the Student-Newman-Keuls test $(\alpha=0.01)$. The result of means separation for the first assessment is not shown. bioluminescence from petioles and main stems was so faint that it was often difficult to see, and the pathogen was occasionally isolated from nonbioluminescent parts of petioles. Thus, bioluminescence was used to determine the proper time for disease assessment, and systemic movement was quantified by sectioning petioles followed by reisolation of the pathogen. In most cases, the plants emitting bioluminescence showed no noticeable signs of infection or visible symptoms in any plant parts when the plants were sectioned for reisolation of the pathogen. The cell density of the pathogen in bioluminescing petioles was estimated to be $>10^{6}$ cells per $1-\mathrm{cm}$ segment.

As judged from the results of three repeated experiments, Marian Seefurth was most susceptible to systemic infection among the cultivars tested, and the pathogen advanced very rapidly and often reached the distal end of petioles in this cultivar (Table 1). The pathogen was recovered from all tested Marian Seefurth plants in all three experiments. In contrast, ARCS and Kalapana were highly resistant to systemic infection. In these two cultivars, systemic movement of the pathogen into leaf petioles or peduncles was confirmed on very few occasions. For example, the pathogen was recovered from only one petiole among all ARCS plants tested in experiments I and II, and from none of the petioles in experiment III. Tropic Mist and UH1060 were less susceptible than Marian Seefurth, but infection became systemic in many plants of these cultivars. Systemic movement of the pathogen was greater in the younger leaf petiole in experiments I and III, but this relationship was not observed in experiment II.

The overall ranking of susceptibility to systemic blight infection for the tested cultivars was determined as follows: Marian Seefurth was most susceptible, followed by Tropic Mist and UH1060; Pink Elf, Nitta, and Alii were moderately susceptible to intermediate, and ARCS and Kalapana were most resistant.

Susceptibility of the eight anthurium cultivars to foliar infection. Pink Elf was most susceptible, with an average percent-

Table 2. Susceptibility of eight anthurium cultivars to bacterial blight in foliar and systemic infection phases

\begin{tabular}{lcc}
\hline Cultivar & $\begin{array}{c}\text { Foliar } \\
\text { infection }\end{array}$ & $\begin{array}{c}\text { Systemic } \\
\text { infection }\end{array}$ \\
\hline Pink Elf & $\mathrm{SS}^{\mathrm{a}}$ & $\mathrm{S}$ \\
Marian Seefurth & $\mathrm{SS}$ & $\mathrm{SS}$ \\
ARCS & $\mathrm{S}$ & $\mathrm{RR}$ \\
UH1060 & $\mathrm{S}$ & $\mathrm{S}$ \\
Tropic Mist & $\mathrm{R}$ & $\mathrm{SS}$ \\
Kalapana & $\mathrm{R}$ & $\mathrm{RR}$ \\
Nitta & $\mathrm{RR}$ & $\mathrm{S}$ \\
Alii & $\mathrm{RR}$ & $\mathrm{S}$ \\
\hline
\end{tabular}

a SS, very susceptible; S, susceptible; R, resistant; RR, very resistant. 
age of infected area reaching $85 \%$ by 54 days after inoculation (Fig. 2). Marian Seefurth and ARCS (71 and 68\%) also were susceptible, followed by UH1060 (49\%). Alii, Nitta, Kalapana, and Tropic Mist were resistant (8 to $15 \%$ ). Overall, cultivar susceptibility in the foliar infection phase did not always correspond to that in the systemic infection phase (Table 2).

Root inoculation. When the bacterium was inoculated through the roots, some of the plants were systemically infected after various intervals. In some plants, bioluminescence was detected from the stem or the petioles as early as 5 weeks after inoculation, whereas in other plants it was not detected until the 10th or 11th week (Fig. 3 ). More plants were systemically infected when transplanted than when undisturbed. Infected plants showed no visible symptoms in any plant parts when bioluminescence was first detected from the petioles. Most infected plants eventually wilted and collapsed (petioles were detached and the stem was rotten) within 15 weeks after inoculation. When the surviving plants were sectioned to reisolate bacteria from various tissues 16 weeks after inoculation, strain V108LRUH1 was recovered from all sampled specimens taken from one Kalapana plant (\#11) and one Marian Seefurth plant (\#25).

\section{DISCUSSION}

The susceptibility ranking among the eight cultivars evaluated for systemic infection did not always correspond to the ranking determined for foliar infection. While Kalapana was resistant to the disease in both foliar and systemic infection phases, Marian Seefurth was susceptible in both phases. However, ARCS was susceptible to foliar infection but was highly resistant to systemic infection. In contrast, Tropic Mist was susceptible to systemic infection but highly resistant to foliar infection. Some growers consider ARCS, Marian Seefurth, and Tropic Mist all "susceptible." Such contradictions were also observed in several Dutch cultivars (data not shown). This phenomenon may create confusion in understanding cultivar
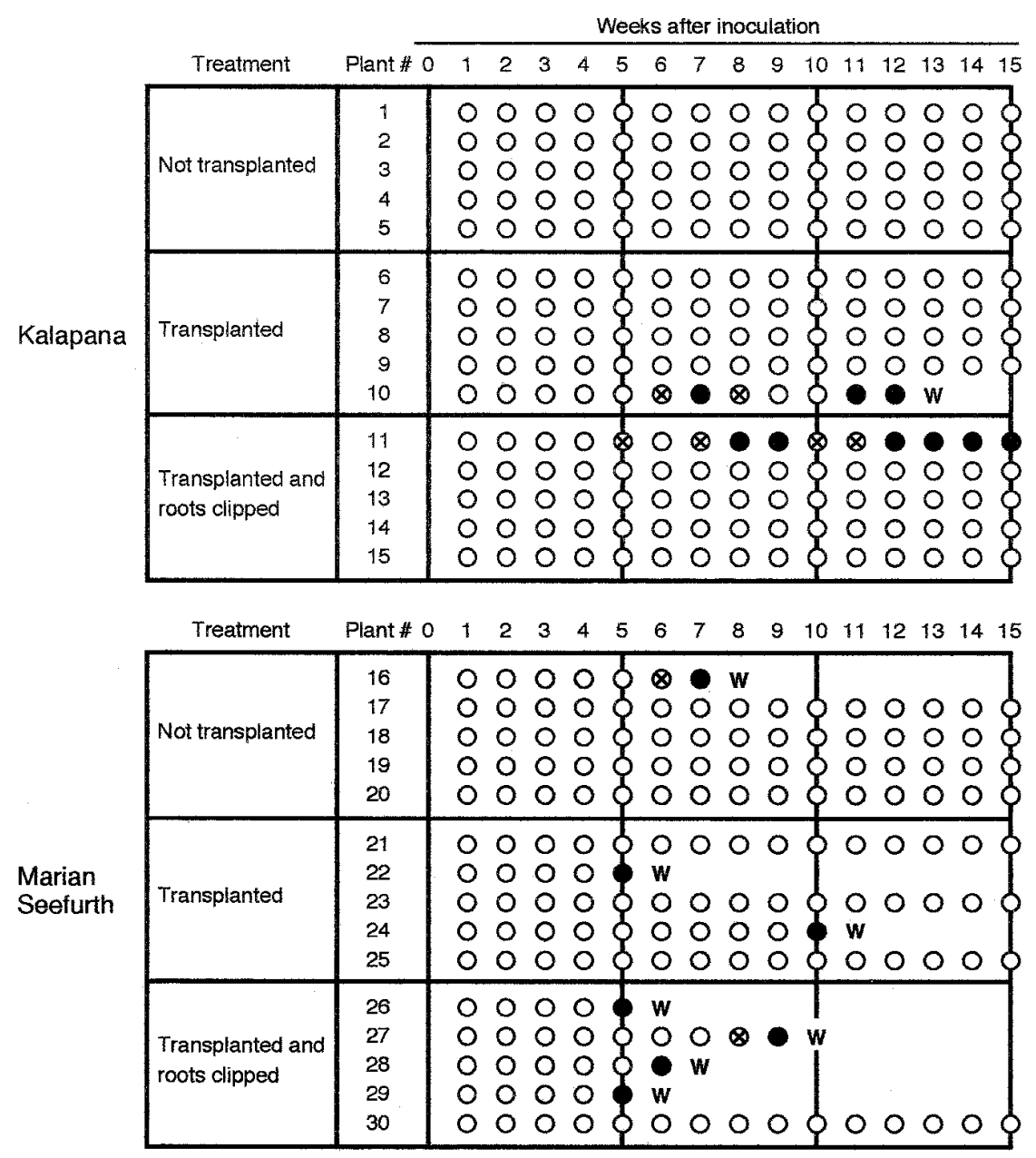

Fig. 3. Occurrence of systemic infections resulting from root inoculations in two anthurium cultivars. Plants were either transplanted, transplanted with clipped roots, or undisturbed (not transplanted). Roots were then inoculated with a bioluminescent strain of Xanthomonas campestris pv. dieffenbachiae and observed weekly for symptom development and light emission in stems and petioles. Each symbol indicates that bioluminescence was observed from the main stem $(\otimes)$ or the main stem plus the petioles $(\bullet)$. W indicates that the entire plant was wilted. susceptibility depending on the stage of plant production. In theory, cultivar susceptibility to systemic infection would be more critical for flower production, since such infections are believed to be transmitted during flower harvest. Once infected, cultivars susceptible to systemic infection (e.g., Marian Seefurth and Tropic Mist) are likely to die in short periods, whereas those resistant to systemic infection (e.g., ARCS) would survive longer and produce more flowers even if leaves are infected. Alii and Nitta are known as "resistant" cultivars among the growers and breeders. Their susceptibility to systemic infection explains why Alii and Nitta show little or no foliar blight but often die due to systemic infection in commercial fields. On the other hand, susceptibility to foliar infection would have a greater impact at earlier propagation stages, since such a stage is less likely to involve wound-creating practices. Thus, susceptibility evaluation for both disease phases is essential for complete understanding of cultivar susceptibility and for improvement of the current disease management strategy.

It appears that cultivar susceptibility in anthuriums is determined by at least two phase-differential mechanisms. No detailed information on physiological or biochemical mechanisms for disease resistance is available for anthuriums, and it is not known how the mechanisms of disease resistance in the foliar infection stage relate to those in the systemic infection stage. It was reported that no structural differences in the hydathode and the adjacent xylem vessel tissues were evident among anthurium cultivars with different levels of susceptibility to the foliar infection phase (26). As for rice and cabbage, it was reported that restricted growth of $X$. campestris pv. campestris and $X$. oryzae pv. oryzae and reduced lesion sizes in incompatible cultivars of their respective hosts were associated with accumulation of lignin-like phenolic compounds in cell walls of host tissues during the initial stage of infection $(9,25)$. In response to pathogen ingress, resistant cabbage cultivars exhibited earlier production of hydrogen peroxide and greater activities of peroxidases in the guttation fluid compared with susceptible cultivars (8). Such enzyme activities catalyze polymerization of the phenolic precursors of lignin (10).

Lignification of the host cell wall also appears to play a key role in disease resistance in anthuriums. The actual sites of infection, determined by detecting light emission from the bioluminescent strains of $X$. campestris pv. dieffenbachiae, in resistant cultivars were restricted to the margins of visible symptoms, but infections were not restricted when the leaf was notched at the leaf margin to expose the xylem vessels (2). However, infection in resistant cultivars eventually advances 
beyond visible symptoms and reaches the leaf xylem and petiole. Thus, lignification may not be the sole mechanism of disease resistance in anthuriums. Kamoun et al. (17) reported that a localized and rapid hypersensitive response in the vascular system of cabbage was associated with the incompatible response to vascular invasion by $X$. campestris. Whether or not such a vascular hypersensitive response was associated with resistance to systemic infection in anthuriums is not known. More detailed histological and physiological studies on anthurium cultivars may provide further understanding of resistance to bacterial diseases.

It was confirmed in this study that infection could occur from the roots of anthuriums and become systemic if sufficient inoculum was present in the root zone. Although root infection was examined only in two cultivars, the results of this study suggest that root infection could have a significant role in occurrence of symptomless infections and disease spread under field conditions. The pathogen is not expected to survive for long periods of time in the planting medium when free of host tissues, but it can survive much longer inside the host tissues (21). Infected leaf tissue often contains $>10^{6}$ cells of the pathogen per $\mathrm{cm}^{2}(7)$, and a single infected leaf $\left(100 \mathrm{~cm}^{2}\right)$ produces as much as $10^{7}$ cells of inoculum per $\mathrm{ml}$ under simulated rain even after it is detached from the main stem (R. Fukui, unpublished). Thus, infected leaf debris left on the ground could provide sites of highly concentrated inoculum for root infection. Transplanting young plants to production fields (cinder beds) inevitably creates wounds on roots. Root infection occurred experimentally even when the plants were not transplanted. Thus, minute wounds or natural openings may also be entry points for the pathogen. Some growers observe that root damage by nematodes may be associated with symptomless systemic infection in adult plants in the field. However, to our knowledge, no supporting experimental evidence has been published. Occurrence of root infection and its significance in disease spread warrant further studies.

In general, no symptom other than wilting was expressed during the early stages of systemic infection. In a few cases, however, a noticeable chlorosis was observed in systemically infected plants. Leaves of UH1060 that were older than the inoculated leaf showed chlorosis, similar to the foliar symptom caused by nitrogen and/or magnesium deficiency. Such leaf chlorosis in aged leaves has been known to be the symptom of systemic infections in certain cultivars (22). Also, the relationship between systemic infection (determined by bioluminescence) and symptom expression (wilting) depended on the cultivar. In systemically infected Marian Seefurth plants, the entire plant wilted within 1 to 2 weeks after the first detection of bioluminescence from plant parts. In contrast, infected Kalapana plants did not wilt until the seventh or eighth week after bioluminescence was first observed in leaf petioles. Presumably, other resistant cultivars also could harbor the pathogen at high densities for extended periods in the stem or petioles without symptom expression.

Systemic infection in anthurium blight has been a little recognized aspect of pathogen growth in the host plant and may be more important for disease control than foliar infection in some cases. Because of its symptomless nature, systemic infection provides additional undetected opportunities for disease spread whether infection is initiated from the root, petioles, or other plant parts. It was shown in this study that systemically infected Kalapana plants survived for as long as 10 weeks without visible symptoms. It was also reported that healthy-looking propagative materials could carry the pathogen symptomlessly for more than a year (23). Such symptomless infections can be the route for introducing the pathogen to a clean field. Whether or not the pathogen is discharged into the guttation fluids of systemically infected plants has not been demonstrated. However, flower harvest or defoliation of systemically infected plants instantaneously provides an opening for the pathogen to exit and spread to neighboring plants. We observed yellow mucoid masses of the pathogen cells oozing from cracks at various positions on the petioles of relatively large anthurium plants (not used for this study). Such eruptions of pathogen cells resembled bacterial cankers, and the masses of bacterial cells are immediate inocula for disease spread. Thus, for longterm disease management, one should not consider that the production fields are free of the disease if the plants are devoid of symptoms and the cultivars are known to be resistant (or tolerant) to systemic infection. Resistant cultivars can carry the pathogen latently in various ways. In fact, it is easier to detect the disease in susceptible plants since they exhibit visible symptoms (foliar symptoms or wilting) much sooner than resistant plants. More attention should be given to resistant and tolerant cultivars in order to improve the current disease management strategies.

\section{ACKNOWLEDGMENTS}

We thank W. T. Nishijima, J. Y. Uchida, and A. R. Y. Kuehnle for critical reading of the manuscript.

\section{LITERATURE CITED}

1. Alvarez, A. M., Lipp, R., and Bushe, B. 1989. Distribution of anthurium blight bacteria on four Hawaiian farms. Pages 20-23 in: Proc. Anthurium Blight Conf., 2nd. J. A. Fernandez and W. T. Nishijima, eds. HITAHR Journal Series 03.10 .89 . University of Hawaii at Manoa, Honolulu.

2. Alvarez, A. M., McElhaney, R., and Fukui, R. 1994. Studies of the infection process in an- thurium blight using a bioluminescent strain of Xanthomonas campestris pv. dieffenbachiae. Pages 31-37 in: Proc. Hawaii Anthurium Industry Conf., 6th. K. M. Delate and E. R. Yoshimura, eds. HITAHR Journal Series 09.12.94. University of Hawaii at Manoa, Honolulu.

3. Alvarez, A. M., Venette, J., and Norman, D. 1994. Relationship of aerosols to anthurium blight. Pages 20-26 in: Proc. Hawaii Anthurium Industry Conf., 5th. K. M. Delate and C. H. M. Tome, eds. HITAHR Journal Series 02.02.94. University of Hawaii at Manoa, Honolulu.

4. Dane, F., and Shaw, J. J. 1993. Growth of bioluminescent Xanthomonas campestris pv. campestris in susceptible and resistant host plants. Mol. Plant-Microbe Interact. 6:786789.

5. Fukui, R., and Alvarez, A. M. 1995. Studies on infection process in bacterial blight of anthurium using a bioluminescent strain of Xanthomonas campestris pv. dieffenbachiae. Pages 12-20 in: Proc. Hawaii Anthurium Industry Conf., 7th. K. M. Delate and E. R. Yoshimura, eds. HITAHR Journal Series 02.03.95. University of Hawaii at Manoa, Honolulu.

6. Fukui, H., Fukui, R., and Alvarez, A. M. 1996. Differences in cultivar resistance of Anthurium to bacterial blight in two phases of disease development. (Abstr.) Phytopathology 86:S51.

7. Fukui, R., Fukui, H., McElhaney, R., Nelson, S. C., and Alvarez, A. M. 1996. Relationship between symptom development and actual sites of infection in leaves of anthurium inoculated with a bioluminescent strain of Xanthomonas campestris pv. dieffenbachiae. Appl. Environ. Microbiol. 62:1021-1028.

8. Gay, P. A., Romenskaya, I. G., Lawrence, C. B., and Tuzun, S. 1996. Oxidative burst associated with resistance to Xanthomonas campestris pv. campestris (XCC). (Abstr.) Phytopathology 86:S24.

9. Gay, P. A., and Tuzun, S. 1995. Analysis of anionic peroxidase isozymes in hydathode fluid of resistant and susceptible cabbage varieties during pathogenesis with Xanthomonas campestris pv. campestris (XCC). (Abstr.) Phytopathology 85:1164.

10. Hammond-Kosack, K. E., and Jones, J. D. G. 1996. Resistance gene-dependent plant defense responses. Plant Cell 8:1773-1791.

11. Hayward, A. C. 1972. A bacterial disease of Anthurium in Hawaii. Plant Dis. Rep. 56:904908.

12. Kado, C. I., and Heskett, M. G. 1970. Selective media for isolation of Agrobacterium, Corynebacterium, Erwinia, Pseudomonas, and Xanthomonas. Phytopathology 60:969976.

13. Kamemoto, H., Kuehnle, A. R., Kunisaki, J. T., Aragaki, M., Higaki, T., and Imamura, J 1990. Breeding for bacterial blight resistance in anthurium. Pages 45-48 in: Proc. Anthurium Blight Conf., 3rd. A. M. Alvarez, ed. HITAHR Journal Series 05.07.90. University of Hawaii at Manoa, Honolulu.

14. Kamemoto, H., Kuehnle, A. R., Kunisaki, J. T., Aragaki, M., Higaki, T., and Imamura, J. 1991. Breeding for bacterial blight resistance in anthurium. Pages 39-41 in: Proc. Hawaii Anthurium Industry Conf., 4th. A. M. Alvarez, D. C. Deardorff, and K. B. Wadsworth, eds. HITAHR Journal Series 04.06.91. University of Hawaii at Manoa, Honolulu.

15. Kamemoto, H., Kuehnle, A. R., Kunisaki, J. T., Aragaki, M., Higaki, T., and ImamuraLichty, J. 1994. Breeding for new and bacterial blight resistance cultivars: A progress report. Pages 39-40 in: Proc. Hawaii Anthurium Industry Conf., 5th. K. M. Delate and C. H. 
M. Tome, eds. HITAHR Journal Series 02.02.94. University of Hawaii at Manoa, Honolulu.

16. Kamemoto, H., Kuehnle, A. R., Kunisaki, J. T., Aragaki, M., and Lichty, J. 1994. Evaluation of University of Hawaii anthurium selections and Dutch cultivars. Pages 5-6 in: Proc. Hawaii Anthurium Industry Conf., 6th. K. M. Delate and E. R. Yoshimura, eds. HITAHR Journal Series 09.12.94. University of Hawaii at Manoa, Honolulu.

17. Kamoun, S., Kamdar, H. K., Tola, E., and Kado, C. I. 1992. Incompatible interactions between crucifers and Xanthomonas campestris involve a vascular hypersensitive response: Role of the hrpX locus. Mol. PlantMicrobe Interact. 5:22-33.

18. Knauss, J. F., and Miller, J. W. 1974. Etiological aspects of bacterial blight of Philodendron oxycardium incited by Xanthomonas dieffenbachiae. Proc. Fla. St. Hortic. Soc. 84:423-428.

19. Lipp, R. L., Alvarez, A. M., Benedict, A. A. and Berestecky, J. 1992. Use of monoclonal antibodies and pathogenicity tests to characterize strains of Xanthomonas campestris pv. dieffenbachiae from aroids. Phytopathology 82:677-682.

20. Nishijima, W. T. 1988. Anthurium blight: An overview. Pages 6-8 in: Proc. Anthurium Blight Conf., 1st. A. Alvarez, ed. HITAHR Journal Series 02.04.88. University of Hawaii at Manoa, Honolulu.

21. Nishijima, W. T. 1989. Current anthurium blight control recommendations. Pages 7-9 in: Proc. Anthurium Blight Conf., 2nd. J. A. Fernandez and W. T. Nishijima, eds. HITAHR Journal Series 03.10.89. University of Hawaii at Manoa, Honolulu.

22. Nishijima, W. T., and Fujiyama, D. K. 1985. Bacterial blight of anthurium. Hawaii Coop- erative Extension Service, Commodity Fact Sheet AN-4 (A):1-3.

23. Norman, D. J., and Alvarez, A. M. 1994. Latent infections of in vitro anthurium caused by Xanthomonas campestris pv. dieffenbachiae. Plant Cell Tissue Organ Cult. 39:55-61.

24. Pohronezny, K., Volin, R. B., and Dankers, W. 1985. Bacterial leaf spot of cocoyam (Xanthosoma caracu), incited by Xanthomonas campestris pv. dieffenbachiae in Florida. Plant Dis. 69:170-173.

25. Reimers, P. J., and Leach, J. E. 1991. Racespecific resistance to Xanthomonas oryzae pv. oryzae conferred by bacterial blight resistance gene $\mathrm{Xa}-10$ in rice (Oryza sativa) involves accumulation of a lignin-like substance in host tissues. Physiol. Mol. Plant Pathol. 38:39-55.

26. Sakai, W. S., Hanohano, T., Sakai, D., Okimoto, S., Furutani, S., and Addison, D. 1991. Further studies of the anatomy and physiology of anthurium in relation to bacterial blight. Pages 47-50 in: Proc. Hawaii Anthurium Industry Conf., 4th. A. M. Alvarez, D. C. Deardorff, and K. B. Wadsworth, eds. HITAHR Journal Series 04.06.91. University of Hawaii at Manoa, Honolulu.

27. Shaw, J. J., Dane, F., Geiger, D., and Kloepper, J. W. 1992. Use of bioluminescence for detection of genetically engineered microorganisms released into the environment. Appl. Environ. Microbiol. 58:267-273.

28. Shaw, J. J., and Kado, C. I. 1986. Development of a Vibrio bioluminescent gene-set to monitor phytopathogenic bacteria during the ongoing disease process in a non-disruptive manner. Bio/Technology 4:560-564.

29. Shaw, J. J., and Kado, C. I. 1987. Direct analysis of the invasiveness of Xanthomonas campestris mutants generated by $\mathrm{Tn} 4431$, a transposon containing a promoterless luciferase cassette for monitoring gene expres- sion. Pages 57-60 in: Molecular genetics of plant-microbe interactions. D. P. S. Verma and N. Nelson, eds. Martinus Nijhoff, Boston.

30. Shehata, S. A , and Nishijima, W. T. 1989. The impact of anthurium blight on the profitability of the industry. Pages 17-19 in: Proc. Anthurium Blight Conf., 2nd. J. A. Fernandez and W. T. Nishijima, eds. HITAHR Journal Series 03.10 .89 . University of Hawaii at Manoa, Honolulu.

31. Shehata, S. A., Nishimoto, M., and Hamilton, M. 1990. The impact of anthurium blight on the profitability of the industry. Pages 3-6 in: Proc. Anthurium Blight Conf., 3rd. A. M. Alvarez, ed. HITAHR Journal Series 05.07.90. University of Hawaii at Manoa, Honolulu.

32. Tanabe, M. J., Baehr, S., Wolff, W., Fernandez, J. A., and Alvarez, A. M. 1994. Anthurium indexing and certification. Pages 9 11 in: Proc. Hawaii Anthurium Industry Conf., 6th. K. M. Delate and E. R. Yoshimura, eds. HITAHR Journal Series 09.12.94. University of Hawaii at Manoa, Honolulu.

33. Tanabe, M. J., Baehr, S., Wolff, W., Fernandez, J. A., Tanaka, R., and Yoshimura, K. 1995. Triple indexing/tissue culture. Page 7 in: Proc. Hawaii Anthurium Industry Conf., 7th. K. M. Delate and E. R. Yoshimura, eds. HITAHR Journal Series 02.03.95. University of Hawaii at Manoa, Honolulu.

34. Tanabe, M. J., Fernandez, J. A., Moriyasu, P. Crane, S., Wolff, W., and Liu, R.-W. 1994. Anthurium in-vitro triple indexing. Pages 8-9 in: Proc. Hawaii Anthurium Industry Conf., 5th. K. M. Delate and C. H. M. Tome, eds HITAHR Journal Series 02.02.94. University of Hawaii at Manoa, Honolulu.

35. Wehlburg, C. 1968. Bacterial leaf spot and tip burn of Philodendron oxycardium caused by Xanthomonas dieffenbachiae. Proc. Fla. St. Hortic. Soc. 81:394-397. 